\title{
Production and antioxidative metabolism in bell pepper grown with saline water in hydroponic system
}

\author{
Nadielan da S. Lima ${ }^{1}$, Marciana B. de Morais ${ }^{2}$, Ennio F. de F. e Silva ${ }^{3}$, Terezinha R. Camara ${ }^{4}$ \& Lilia Willadino ${ }^{2}$ \\ ${ }^{1}$ Instituto Federal de Educação, Ciência e Tecnologia de Pernambuco/Campus de Belo Jardim. Belo Jardim, PE. E-mail: nadielanlima@hotmail.com \\ ${ }^{2}$ Universidade Federal Rural de Pernambuco/Departamento de Biologia. Recife, PE. E-mail: marciana.bio@gmail.com; willadino.lilia@gmail.com \\ (Corresponding author) \\ ${ }^{3}$ Universidade Federal Rural de Pernambuco/Departamento de Engenharia Agrícola. Recife, PE. E-mail: enio.fsilva@ufrpe.br \\ ${ }^{4}$ Universidade Federal Rural de Pernambuco/Departamento de Química. Recife, PE. E-mail: teca.camara@gmail.com
}

\section{Key words:}

electrical conductivity photosynthetic pigment antioxidant enzymes

\begin{abstract}
A B S T R A C T
This study aimed to evaluate the effect of salt stress on production and antioxidative defense metabolism of two bell pepper cultivars (Capsicum annuum L.) grown hydroponically. The experimental design was in randomized blocks, with treatments arranged in a $5 \times 2$ factorial scheme with five replicates. The treatments consisted of five salinity levels of the nutrient solution $\left(2.0,3.5,4.5,5.5\right.$ and $\left.6.5 \mathrm{dS} \mathrm{m}^{-1}\right)$ with two bell pepper cultivars, 'Bruno' and 'Rúbia'. Biomass and yield were reduced with increasing salinity. The contents of chlorophyll $\mathrm{a}, \mathrm{b}$ and total decreased with increasing salinity. There was an increase in proline content and activity of superoxide dismutase (SOD), catalase (CAT) and ascorbate peroxidase (APX), showing the activation of the antioxidant defense mechanism. The higher yield in the cv. 'Rúbia', as well as the greater activity of the APX and the lower levels of chlorophyll content, reflect the best acclimatization of this cultivar to saline stress. The estimated yield of the cv. 'Rúbia', $39.9 \mathrm{t} \mathrm{ha}^{-1}$ when grown with ECs of up to $3.5 \mathrm{dS} \mathrm{m} \mathrm{m}^{-1}$, indicates the feasibility of its commercial cultivation in hydroponic conditions.
\end{abstract}

\section{Palavras-chave:} condutividade elétrica pigmento fotossintético enzimas antioxidativas

\section{Produção e metabolismo antioxidativo em pimentão cultivado com água salina em sistema hidropônico}

\begin{abstract}
R E S U M O
Este trabalho foi realizado com o objetivo de avaliar o efeito do estresse salino sobre a produção e o metabolismo de defesa antioxidativa de duas cultivares de pimentão (Capsicum annuum L.), cultivadas em sistema hidropônico. $\mathrm{O}$ delineamento experimental foi em blocos casualizados, com os tratamentos arranjados em esquema fatorial $5 \times 2$, com cinco repetições. Os tratamentos consistiram da combinação de cinco níveis de salinidade da solução nutritiva $\left(2,0 ; 3,5 ; 4,5 ; 5,5\right.$ e $\left.6,5 \mathrm{dS} \mathrm{m}^{-1}\right)$ com duas cultivares de pimentão (Bruno e Rúbia). A biomassa e a produção foram reduzidas com o incremento da salinidade. Os teores de clorofila a, b e total, diminuíram com o aumento da salinidade. Houve aumento no teor de prolina e na atividade das enzimas superóxido dismutase (SOD), catalase (CAT) e ascorbato peroxidase (APX), evidenciando a ativação do mecanismo de defesa antioxidativo. A maior produção de frutos na cv. Rúbia, bem como a maior atividade da APX e os menores teores de clorofilas refletem a melhor aclimatação desta cultivar ao estresse salino. A produtividade estimada da cv. Rúbia, 39,8 $\mathrm{t} \mathrm{ha}^{-1}$, quando cultivada com uma CEs de até $3,5 \mathrm{dS} \mathrm{m}^{-1}$, indica a viabilidade de seu cultivo comercial em condições hidropônicas.
\end{abstract}




\section{INTRODUCTION}

Bell pepper (Capsicum annuum L.) cultivation is widely practiced in family farming, in semi-arid areas of Northeast Brazil. In these areas, however, a large portion of the water sources is compromised for the utilization in agriculture due to the excess of salts (Nunes et al., 2013). In hydroponic systems, plant tolerance to salinity is higher in comparison to the conventional system, since the effects of salinity on the crops are reduced due to the great availability of water and nutrients, guaranteed by the high frequency of nutrient solution application and low influence of the matrix potential (Santos et al., 2016).

Salinity is an abiotic stress that promotes morphological and physiological alterations in the entire plant and results in growth reduction (Munns \& Tester, 2008). Salt stress triggers a secondary stress, oxidative, which is characterized by the increase in the generation of reactive oxygen species (ROS) (Gill \& Tuteja, 2010), capable of causing damages to the macromolecules and cell structures and even leading to plant death (Foyer \& Noctor, 2009). To combat ROS, plants have developed an efficient antioxidative defense mechanism, which acts through the synthesis of metabolites and activation of a complex enzymatic system (Barbosa et al., 2014). Among these enzymes, superoxide dismutase (SOD), catalase (CAT) and ascorbate peroxidase (APX) stand out. SOD is responsible for the dismutation of the superoxide radical $\left(\mathrm{O}_{2}{ }^{*}\right)$ to hydrogen peroxide $\left(\mathrm{H}_{2} \mathrm{O}_{2}\right)$, which in turn is eliminated and converted to water by both APX and CAT (Gill \& Tuteja, 2010).

Considering the low tolerance of bell pepper, which has maximum salinity threshold of $1.5 \mathrm{dS} \mathrm{m}^{-1}$ in the soil, without yield losses (Villas Bôas et al., 2002), as well as the importance of using brackish water, this study aimed to evaluate the effect of salt stress on the antioxidative defense metabolism and maintenance of productive capacity of two bell pepper cultivars, in hydroponic system.

\section{Material ANd Methods}

The experiment was carried out for 120 days, in a protected environment at the Department of Agricultural Engineering UFRPE, in the city of Recife, PE (latitude: $8^{\circ} 3^{\prime} 15^{\prime \prime}$ S, longitude: $34^{\circ} 52^{\prime} 53^{\prime \prime} \mathrm{W}$ ), using an open hydroponic system with coconut fiber (powder) as substrate in 8-L polyethylene pots. The nutrient solution was applied to the plants through pressurecompensating drippers with nominal flow rate of $4 \mathrm{~L} \mathrm{~h}^{-1}$. The seedlings were transplanted to the pots 35 days after sowing, at spacing of $0.5 \mathrm{~m}$ between pots and $1.0 \mathrm{~m}$ between rows, equivalent to a planting density of 20,000 plants ha-1.

The saline solutions were prepared by adding $\mathrm{NaCl}$ to the water until reaching four levels of electrical conductivity in the solutions (ECs): 1.5, 2.5, 3.5 and $4.5 \mathrm{dS} \mathrm{m}^{-1}$. After the addition of $\mathrm{NaCl}$, the solutions received salts of the nutrient solution of Furlani (Furlani et al., 1999), resulting in final ECs of 3.5, $4.5,5.5$ and $6.5 \mathrm{dS} \mathrm{m}^{-1}$, respectively. A control treatment was maintained using only the solution of Furlani (ECs of $2.0 \mathrm{dS}$ $\left.\mathrm{m}^{-1}\right)$. The nutrient solution was monitored every two days during the crop cycle, through readings of $\mathrm{pH}$ and $\mathrm{EC}$. The $\mathrm{pH}$ was adjusted, when necessary, to be between 5.0 and 6.0. Plants were irrigated once a day, considering the capacity of the pot.

Fruit fresh matter (FFM) was determined by weighing the fruits of each one of the five harvests. Leaf fresh matter (LFM) was determined at the end of the experiment when plants were collected and weighed on analytical scale. Leaf dry matter (LDM) and fruit dry matter (FDM) were obtained after drying the materials in a forced-air oven $\left(65 \pm 5^{\circ} \mathrm{C}\right)$. Production was determined based on the product between the mean weight of the fresh fruits and the total number of commercial fruits harvested, expressed in $\mathrm{kg}_{\text {plant }}{ }^{-1}$.

For the determination of the contents of chlorophylls, proline and activity of the enzymes superoxide dismutase (SOD), catalase (CAT) and ascorbate peroxidase (APX), two leaves were collected from mid-portion of the plants ( 90 days after transplanting), involved in aluminum foil, immersed and maintained in liquid nitrogen until the storage in a freezer, for subsequent analyses. The contents of chlorophyll a, b and total were determined based on the methodology proposed by Arnon (1949). Proline content was determined according to the method proposed by Bates et al. (1973). The activities of SOD, CAT and APX were determined according to the methodologies described by Beers \& Sizer (1952), Giannopolitis \& Ries (1977) and Nakano \& Asada (1981), respectively.

The experimental design was randomized blocks and the treatments were arranged in a $5 \times 2$ factorial scheme, with five replicates. The treatments consisted in the combination of five levels of electrical conductivity (ECs) of the nutrient solution $\left(2.0 ; 3.5 ; 4.5 ; 5.5\right.$ and $\left.6.5 \mathrm{dS} \mathrm{m}^{-1}\right)$ with two bell pepper cultivars, 'Bruno' and 'Rúbia', totaling ten treatments. Each plot had two plants, one per pot.

The variables were subjected to analysis of variance. The quantitative factor, relative to the nutrient solution salinity levels, was analysed through regression and the qualitative factor, relative to the bell pepper cultivars, was analysed through comparison of means by Tukey test at 0.05 probability level.

\section{Results AND Discussion}

There was significant effect of the interaction between cultivars and salinity levels only on leaf fresh matter (LFM) and production. For the factor cultivars, only fruit fresh matter (FFM) and production were significant. For the factor nutrient solution salinity, there was significance on all variables, except fruit dry matter (FDM) (Table 1).

The reductions in LFM were of the order of 42.24 and $41.01 \mathrm{~g}$ per unit of ECs $\left(\mathrm{dS} \mathrm{m}^{-1}\right)$, in the cultivars 'Bruno' and 'Rúbia', respectively (Figure 1A). The reduction in fresh and dry matter as a function of the increment in salinity is frequent in the Solanaceae family, and has been observed in hydroponic cultivation with eggplant (Bosco et al., 2009), bell pepper (Nunes et al., 2013) and tomato (Santos et al., 2016).

The production of the studied cultivars was reduced by the increment in salinity (Figure 1D). The cv. 'Rúbia', however, stood out with highest fruit production. When grown under salt stress, approximately $3.5 \mathrm{dS} \mathrm{m}^{-1}$, this cultivar showed yield 
Table 1. Summary of the analysis of variance and mean values of leaf fresh matter (LFM), leaf dry matter (LDM), fruit fresh matter (FFM), fruit dry matter (FDM) and production, as a function of nutrient solution electrical conductivity (ECs) in two bell pepper cultivars (C), in hydroponic system

\begin{tabular}{|c|c|c|c|c|c|c|}
\hline \multirow{2}{*}{$\begin{array}{c}\text { Source } \\
\text { of variation }\end{array}$} & \multirow{2}{*}{ DF } & \multicolumn{5}{|c|}{ Mean square } \\
\hline & & LFM & LDM & FFM & FDM & Production \\
\hline Block & 4 & 1357 ns & 44.09 ns & 775.48 ns & $8.16^{\mathrm{ns}}$ & 0.29 * \\
\hline ECs & 4 & $53175.75^{\star *}$ & 1085.34 ** & $5407.61 * *$ & $11.98^{\mathrm{ns}}$ & 10.57 ** \\
\hline C & 1 & $3612.5^{\mathrm{ns}}$ & $87.78^{\mathrm{ns}}$ & 8929.55 ** & $7.75^{\mathrm{ns}}$ & 4.94 ** \\
\hline $\mathrm{ECs} \times \mathrm{C}$ & 4 & 2701.25 * & 61.21 ns & $530.41^{\mathrm{ns}}$ & $1.91^{\mathrm{ns}}$ & 0.34 * \\
\hline Error & 36 & 979.22 & 32.28 & 838.35 & 4.79 & 0.08 \\
\hline \multirow[t]{2}{*}{ CV (\%) } & - & 11.35 & 13.95 & 31.02 & 31.44 & 25.92 \\
\hline & & & & Mean values $\#$ & & \\
\hline 'Bruno' & - & $284.2 \mathrm{a}$ & $42.05 \mathrm{a}$ & 79.96 b & $6.57 \mathrm{a}$ & $0.83 \mathrm{~b}$ \\
\hline 'Rúbia' & - & $267.2 \mathrm{a}$ & $39.40 \mathrm{a}$ & $106.69 \mathrm{a}$ & $7.36 \mathrm{a}$ & $1.46 \mathrm{a}$ \\
\hline
\end{tabular}

\#Means followed by the same letter in the row do not differ at 0.05 probability level by Tukey test; nsNot significant; * Significant at 0.05 ; * ${ }^{*}$ Significant at 0.01 . Mean values for LFM, LDM, FFM, FDM expressed in $\mathrm{g}$ and production in $\mathrm{kg} \mathrm{plant}^{-1}$

of $1.99 \mathrm{~kg}$ plant ${ }^{-1}$, which corresponds to a potential yield of 39.8 tha ${ }^{-1}$, since the planting density was equivalent to 20,000 plants $\mathrm{ha}^{-1}$. Considering that the yield of bell pepper cultivated at the field, without salt stress, is around 25-40 $\mathrm{t} \mathrm{ha}^{-1}$ (EMBRAPA, 2016), it is evident the potential of using brackish water, with ECs of

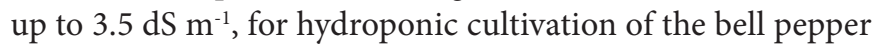
cv. 'Rúbia'. The hydroponic cultivation system differs from the cultivation in soil mainly because in the latter the salinity strongly contributes to a reduction in the matrix potential and, consequently, in the total water potential, reducing its absorption by the plant. In the hydroponic cultivation, however, the matrix potential is virtually nullified, due to the state of saturation to which plants are subjected, and only the osmotic potential remains, which results in an increase of total water potential and, as a result, reduces the negative effects of the utilization of brackish water (Soares et al., 2007). Plants subjected to the highest salinity level of the nutrient solution (ECs of $6.5 \mathrm{dS} \mathrm{m}^{-1}$ ), on the other hand, showed high reductions, $91 \%$ for the cv. 'Bruno' and $85 \%$ for the cv. 'Rúbia'. Nunes et al. (2013) observed losses of fruit production in bell pepper, cv. 'Margarita', in the treatment with higher EC $\left(9.23 \mathrm{dS} \mathrm{m}^{-1}\right)$, of the order of $65.4,52.58$ and $40.47 \%$, at 24, 85 and 120 days of exposure to nutrient solution salinity, respectively. According to Munns \& Tester (2008), the reduction of biological or economic yield is the main effect of salinity on the plant and is, in general, attributed to various physiological and biochemical processes in the cell or at molecular levels.

In LDM, the mean reductions were equal to $5.95 \mathrm{~g}$ per unit of ECs, for both cultivars (Figure 1B). In FFM, there was a reduction of $13.25 \mathrm{~g}$ per $\mathrm{dS} \mathrm{m}^{-1}$ for both cultivars (Figure $1 \mathrm{C})$. It is noted that the $\mathrm{cv}$. 'Rúbia' showed, on average, higher FFM (Table 1). There was no fit of lines for FDM regarding the salinity levels and the mean value was equal to $6.96 \mathrm{~g}$ for the cultivars. It should be highlighted that, for this crop, the focus is on FFM, since this is the form in which the fruit is commercialized (EMBRAPA, 2016).

The reduction of growth and production in plants subjected to salinity are due to osmotic and toxic effects, caused by the excess of $\mathrm{Na}^{+}$and $\mathrm{Cl}^{-}$, which include especially the restriction of $\mathrm{CO}_{2}$ assimilation and reduction in chlorophyll content, consequently leading to reduction in photosynthetic rate (Munns \& Tester, 2008).

There was no significant effect of the interaction between the factors on the contents of chlorophylls $\mathrm{a}, \mathrm{b}$ and total.
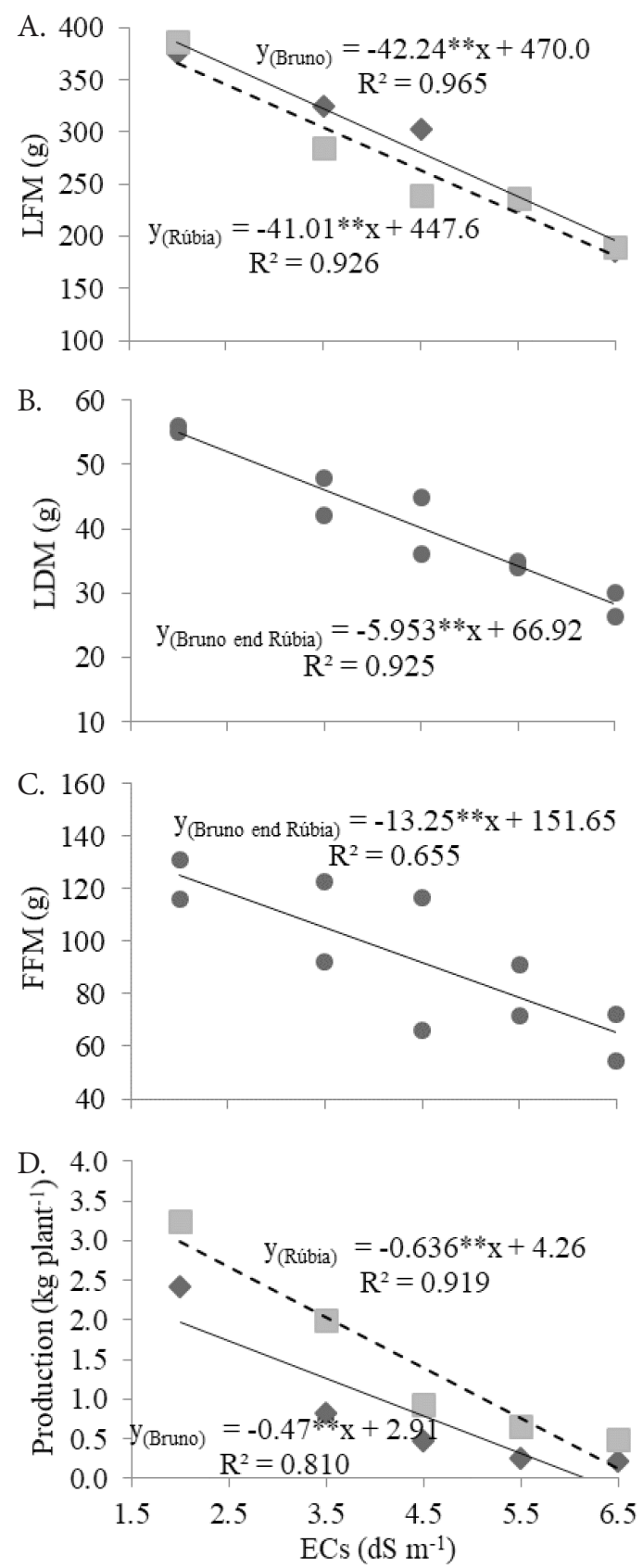

Figure 1. Dispersion graphs and regression equations for leaf fresh matter - LFM (A), leaf dry matter - LDM (B), fruit fresh matter - FFM (C) and mean fruit production (D) of the cultivars 'Bruno' and 'Rúbia', as a function of the nutrient solution electrical conductivity (ECs) in hydroponic system 
Nutrient solution salinity influenced only the contents of chlorophyll a and total (Table 2 and Figure 2A, B).

The chlorophyll content was lower in the cv. 'Rúbia'. The reduction in chlorophyll a contents in the chloroplasts of stressed plants is a form of preventing the formation of superoxide by the transfer of excitation energy from these pigments to the oxygen, due to the low demand of electrons by the Electron Transport Chain. This decrement in the photochemical conversion rate results from the low $\mathrm{CO}_{2}$ concentration, due to stomatal closure, caused by salt stress conditions (Dabrowska et al., 2007). In study conducted with five pepper cultivars (Capsicum frutescens L.) subjected to salt stress, the reduction in the contents of chlorophylls a and b was mainly attributed to the damages caused by the salt in the lipid-pigment-protein complex (Zhani et al., 2012).

Table 2. Summary of the analysis of variance and mean values for the contents of chlorophyll $a, b$ and total ( $\left.\mathrm{mg} \mathrm{g}^{-1} \mathrm{FM}\right)$, as a function of the nutrient solution electrical conductivity (ECs) in bell pepper cultivars (C) in hydroponic system

\begin{tabular}{lcccc}
\hline $\begin{array}{c}\text { Source } \\
\text { of variation }\end{array}$ & DF & \multicolumn{3}{c}{ Mean square } \\
\cline { 3 - 5 } Block & 4 & Chlorophyll a & Chlorophyll b & Total chlorophyll \\
ECs & 4 & $27.12^{*}$ & $1.31^{\text {ns }}$ & $26.83^{*}$ \\
C & 1 & $49.39^{* *}$ & $2.93^{\mathrm{ns}}$ & $40.65^{* *}$ \\
ECs x C & 4 & $6.94^{\text {ns }}$ & $2.21^{\text {ns }}$ & $63.54^{*}$ \\
Error & 36 & 3.87 & 1.37 & $20.98^{\text {ns }}$ \\
CV (\%) & - & 16.67 & 17.60 & 16.93 \\
\hline & & & Mean values \# \\
'Bruno' & - & $12.79 \mathrm{a}$ & $7.01 \mathrm{a}$ & $19.69 \mathrm{a}$ \\
'Rúbia' & - & $10.81 \mathrm{~b}$ & $6.30 \mathrm{~b}$ & $17.44 \mathrm{~b}$ \\
\hline
\end{tabular}

\#Means followed by the same letter in the column do not differ at 0.05 probability level by

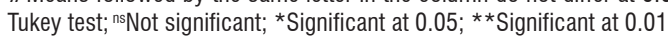
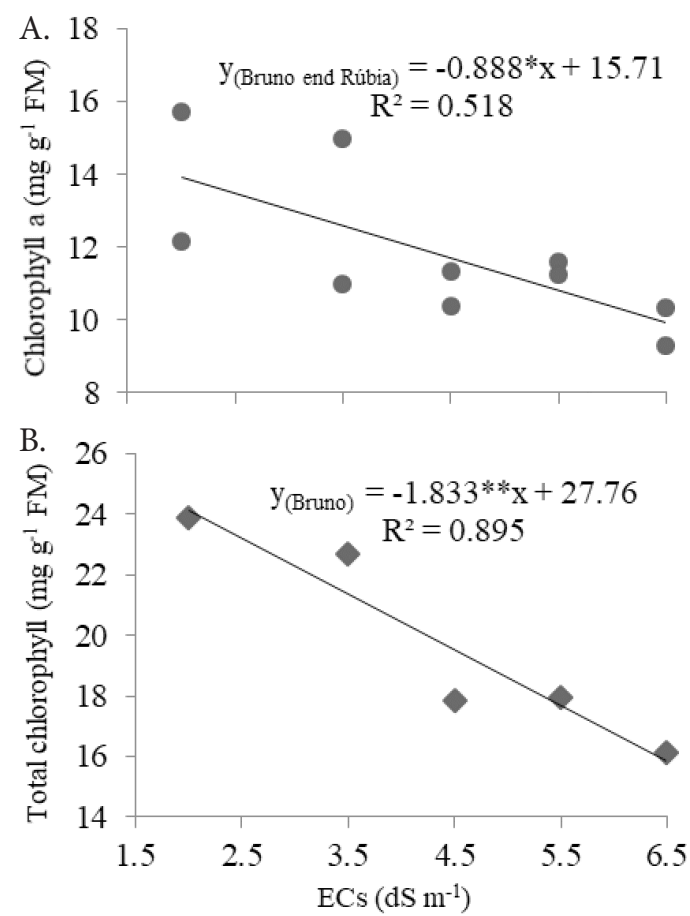

Figure 2. Dispersion graphs and regression equations for the contents of chlorophyll a (A) and total chlorophyll (B) in the leaf tissue of the cultivars 'Bruno' and 'Rúbia' as a function of the nutrient solution salinity (ECs), in hydroponic system
In the antioxidant metabolism, the interaction between factors was significant only for APX activity. There was significant effect of the factor salinity on proline content and activity of the enzymes SOD, CAT and APX. Regarding the factor cultivars, there was difference for proline content and APX activity (Table 3 ).

The cv. 'Rúbia' showed higher APX activity in comparison to the cv. 'Bruno', in all treatments (Figure 3D). The higher APX activity in the cv. 'Rúbia', including in the treatment without $\mathrm{NaCl}$ addition, suggests that it is a genotypic characteristic. APX is a very important enzyme for the removal of $\mathrm{H}_{2} \mathrm{O}_{2}$ in both cytosol and chloroplast (Foyer \& Noctor, 2009). Studies conducted with other species of the Solanaceae family demonstrated that genotypes with higher tolerance to salinity showed higher APX activity compared to sensitive genotypes (Razavizadeh \& Ehsanpour, 2009, Lin \& Pu, 2010). In this context, the higher intrinsic activity of this enzyme in bell pepper genotypes may become an indication of tolerance to salinity.

According to Figure 3A, proline content increased by $37 \%$ per unit increase in nutrient solution salinity $\left(\mathrm{dS} \mathrm{m}^{-1}\right)$, in both cultivars. On average, the cv. 'Bruno' showed higher proline contents compared with the cv. 'Rúbia', when subjected to salt stress. The accumulation of proline is a common physiological response in plants exposed to various abiotic stress factors. The functions of proline in the tolerance to stress are still a topic of debate, since its synthesis and catabolism are regulated by multiple cell mechanisms, of which only a few are known (Bhaskara et al., 2015). Proline has been known to contribute to stabilization of subcellular structures, elimination of free radicals and buffering of the cell redox potential (Kaur \& Asthir, 2015).

SOD activity increased on average by $20 \%$ per unit increase in nutrient solution salinity $\left(\mathrm{dS} \mathrm{m}^{-1}\right)$, for both cultivars (Figure 3B). Aktas et al. (2009) in a study with C. annuum varieties subjected to salt stress of 75 and $150 \mathrm{mM}$ of $\mathrm{NaCl}$, observed that while the tolerant genotype, wild, exhibited increase in SOD activity, the sensitive genotype, widely cultivated in Turkey, showed reduction. SOD is the first line of defense against ROS, catalyzing the reaction of dismutation of the superoxide radical $\left(\cdot \mathrm{O}_{2}^{-}\right)$to hydrogen peroxide $\left(\mathrm{H}_{2} \mathrm{O}_{2}\right)$. The formed $\mathrm{H}_{2} \mathrm{O}_{2}$, however, is also a ROS that, when accumulated, results in damages to the

Table 3. Summary of the analysis of variance and mean values for proline ( $\left.\mathrm{mg} \mathrm{g}^{-1} \mathrm{FM}\right)$, superoxide dismutase - SOD $\left(\mathrm{U} \mathrm{mg}_{\mathrm{prot}}{ }^{-1} \mathrm{~min}^{-1}\right)$, catalase - CAT $\left(\mathrm{mol} \mathrm{H}_{2} \mathrm{O}_{2} \mathrm{mg}_{\text {prot }}{ }^{-1} \mathrm{~min}^{-1}\right)$ and ascorbate peroxidase - APX ( $\left.\mathrm{mol} \mathrm{H}_{2} \mathrm{O}_{2} \mathrm{mg} \mathrm{prot}^{-1} \mathrm{~min}^{-1}\right)$, as a function of nutrient solution salinity (ECs) in two bell pepper cultivars $(C)$, in hydroponic system

\begin{tabular}{|c|c|c|c|c|c|}
\hline \multirow{2}{*}{$\begin{array}{c}\text { Source } \\
\text { of variation }\end{array}$} & \multirow{2}{*}{ DF } & \multicolumn{4}{|c|}{ Mean square } \\
\hline & & Proline & SOD & CAT & APX \\
\hline Block & 4 & $0.05^{\mathrm{ns}}$ & 1891.63 ** & 1.17 * & $160.97^{\text {ns }}$ \\
\hline ECs & 4 & $0.97 * *$ & 2062.58 ** & 2.52 ** & 2089.98 ** \\
\hline C & 1 & 0.90 ** & 100.27 ns & $1.06^{\mathrm{ns}}$ & 981.73 ** \\
\hline ECs $\times C$ & 4 & $0.07^{\text {ns }}$ & 130.59 ns & $0.3^{\mathrm{ns}}$ & 9.68 * \\
\hline Error & 36 & 0.05 & 414.72 & 0.38 & 102.15 \\
\hline \multirow[t]{2}{*}{ CV (\%) } & - & 19.16 & 26.19 & 43.91 & 22.15 \\
\hline & & \multicolumn{4}{|c|}{ Mean values \# } \\
\hline 'Bruno' & - & $1.39 \mathrm{a}$ & $76.35 \mathrm{a}$ & $1.26 \mathrm{a}$ & $41.19 b$ \\
\hline ‘Rúbia' & - & $1.12 b$ & $79.18 \mathrm{a}$ & $1.55 \mathrm{a}$ & $50.05 \mathrm{a}$ \\
\hline
\end{tabular}

\#Means followed by the same letter in the column do not differ at 0.05 probability level by

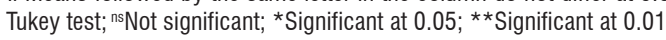



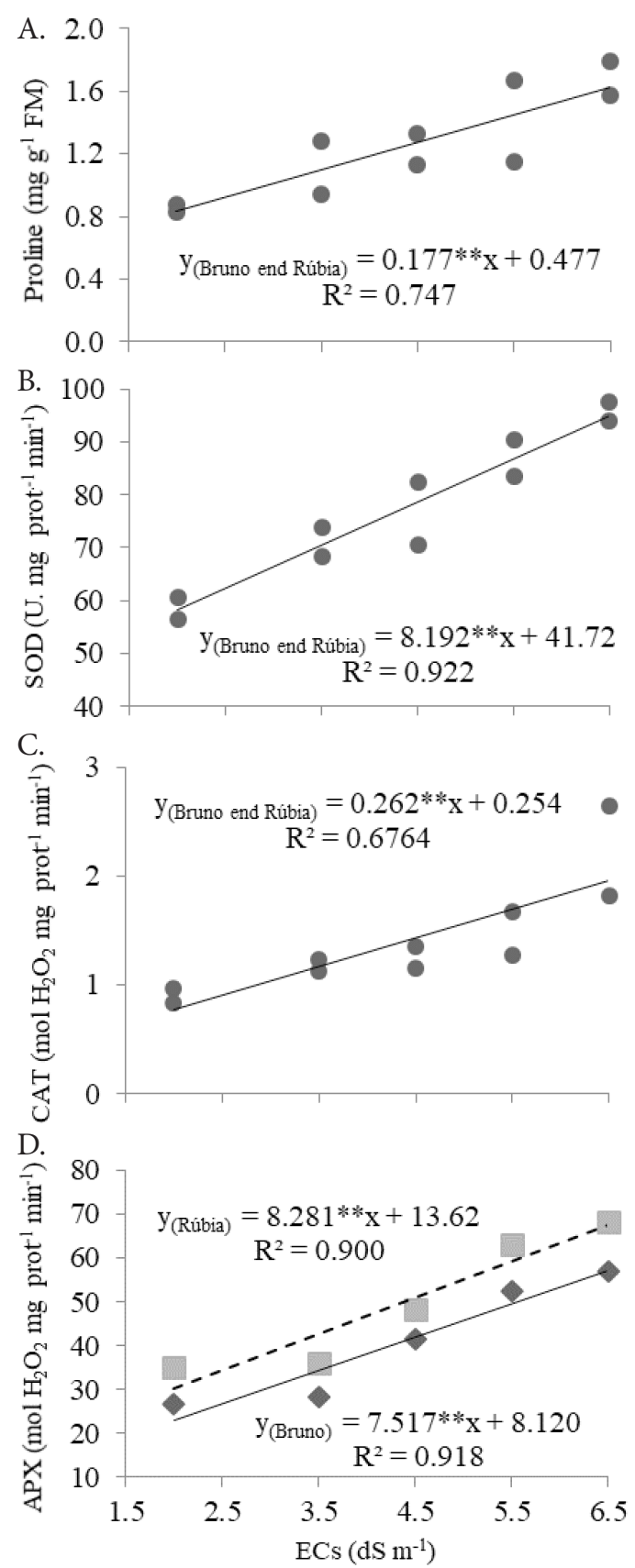

Figure 3. Dispersion graphs and regression equations for proline content $(\mathrm{A})$ and activities of superoxide dismutase - SOD (B), catalase - CAT (C) and ascorbate peroxidase APX (D) in the leaf tissue of bell pepper cultivars ('Bruno' and 'Rúbia') as a function of nutrient solution salinity (ECs), in hydroponic system

plant. The elimination of $\mathrm{H}_{2} \mathrm{O}_{2}$ is performed by the enzymes CAT and APX (Gill \& Tuteja, 2010).

CAT activity also increased with the increment of salinity, in both cultivars (Figure 3C), with maximum increase close to $150 \%$ when treated with the highest ECs $\left(6.5 \mathrm{dS} \mathrm{m}^{-1}\right)$. The increase in CAT activity favors the elimination of $\mathrm{H}_{2} \mathrm{O}_{2}$, both generated by SOD and produced in the photorespiration. The increase in CAT activity in response to salt stress was also observed in the C. annuum cultivar 'Cho Jinda', when subjected to salinity of 50 and $200 \mathrm{mM}$ of $\mathrm{NaCl}$, as described by Chookhampaeng (2011).

The higher yield of the cv. 'Rúbia' reflects strategies of tolerance to stress, which differ from the cv. 'Bruno', since it has greater APX activity and, therefore, greater capacity of $\mathrm{H}_{2} \mathrm{O}_{2}$ elimination, especially in chloroplasts, as well as greater capacity of reduction of chlorophyll contents, favoring the photosynthetic process. As claimed by Fikret et al. (2013), the genetic variability within a species is a valuable tool in the search for genotypes with higher tolerance to salinity.

\section{Conclusions}

1. Nutrient solution salinity leads to reduction of biomass production in the bell pepper cultivars 'Rúbia' and 'Bruno'.

2. The cv. 'Rúbia' has higher fruit production, reflecting greater acclimatization capacity through higher efficiency of the antioxidative metabolism and maintenance of lower contents of photosynthetic pigments under salt stress conditions. The estimated yield of the cv. 'Rúbia' demonstrates that its hydroponic cultivation is potentially viable, without commercial loss, using brackish water with ECs of up to 3.5 $\mathrm{dS} \mathrm{m}^{-1}$.

\section{Literature Cited}

Aktas, H.; Abak, K.; Cakmak, I. Genotypic variation in the response of pepper to salinity. Scientia e Horticulturae, v.110, p.260-266, 2009. https://doi.org/10.1016/j.scienta.2006.07.017

Arnon, D. I. Copper enzymes in isolated chloroplasts. Polyphenoloxidase in Beta vulgaris. Plant Physiology, v.24, p.1-15, 1949. https://doi. org/10.1104/pp.24.1.1

Barbosa, M. R.; Silva, M. M. de A.; Willadino, L.; Ulisses, C.; Camara, T. R. Geração e desintoxicação enzimática de espécies reativas de oxigênio em plantas. Ciência Rural, v.44, p.453-460, 2014. https:// doi.org/10.1590/S0103-84782014000300011

Bates, L. S; Waldren, R. P.; Teare, I. D. Rapid determination of free proline for water-stress studies. Plant and Soil, v.39, p.205-207, 1973. https://doi.org/10.1007/BF00018060

Bhaskara, G. B.; Yang, T. H.; Verslues, P. E. Dynamic proline metabolism: Importance and regulation in water limited environments. Frontiers in Plant Science, v.6, p.1-7, 2015. https:// doi.org/10.3389/fpls.2015.00484

Beers, Jr. R. F.; Sizer, I. W. A spectrophotometric method for measuring the breakdown of hydrogen peroxide by catalase. Journal of Biological Chemistry, v.195, p.133-140, 1952.

Bosco, M. R. de O.; Oliveira, A. B. de; Hernandez, F. F. F.; Lacerda, C. F. de. Efeito do $\mathrm{NaCl}$ sobre o crescimento, fotossíntese e relações hídricas de plantas de berinjela. Revista Ceres, v.56, p.296-302. 2009.

Chookhampaeng, S. The effect of salt stress on growth, chlorophyll content proline content and antioxidative enzymes of pepper (Capsicum annuum L.) seedling. European Journal of Scientific Research, v.49, p.103-109. 2011.

Dabrowska, G.; Kata, A.; Goc, A.; Szechynska-Hebda, M.; Skrzypek, E. Characteristics of the plant ascorbate peroxidase family. Acta Biologica Cracoviensia, v.49, p.7-17, 2007.

EMBRAPA - Empresa Brasileira de Pesquisa Agropecuária. Centro Nacional de Pesquisa de Hortaliças: Pimentão. Brasília-DF: Embrapa Hortaliças. 2016. Disponível em: <http://www.cnph. embrapa.br/capsicum/cpimentao.htm>. Acesso em: 24 Ago. 2016. 
Fikret, Y.; Manar, T.; Şebnem, E.; Şebnem, K.; Özlem, U. SOD, CAT, GR and APX enzyme activities in callus tissues of susceptible and tolerant eggplant varieties under salt stress. Research Journal of Biotechnology, v.8, p.45-51, 2013.

Foyer, C. H; Noctor, G. Redox regulation in photosynthetic organisms: Signaling, acclimation, and practical implications. Antioxidants \& Redox Signaling, v.11, p.862-905, 2009. https://doi.org/10.1089/ ars.2008.2177

Furlani, P. R.; Silveira, L. C. P.; Bolonhezi, D.; Faquin, V. Cultivo hidropônico de plantas. 1.ed. Campinas: Instituto Agronômico, 1999. 52p. Boletim Técnico, 180

Giannopolitis, C. N.; Ries, S. K. Superoxide dismutases: I. Occurrence in higher plants. Plant Physiology, v.59, p.309-314, 1977. https:// doi.org/10.1104/pp.59.2.309

Gill, S. S.; Tuteja, N. Reactive oxygen species and antioxidant machinery in abiotic stress tolerance in crop plants. Plant Physiology and Biochemistry, v.48, p.909-930, 2010. https://doi. org/10.1016/j.plaphy.2010.08.016

Kaur, G.; Asthir, B. Proline: A key player in plant abiotic stress tolerance. Biologia Plantarum, v.59, p.609-619, 2015. https://doi. org/10.1007/s10535-015-0549-3

Lin, K. H, Pu, S. F. Tissue- and genotype-specific ascorbate peroxidase expression in sweet potato in response to salt stress. Biologia Plantarum, v.54, p.664-670. 2010. https://doi.org/10.1007/ s10535-010-0118-8

Munns, R.; Tester, M. Mechanisms of salinity tolerance. Annual Review of Plant Biology, v.59, p.651-681, 2008. https://doi. org/10.1146/annurev.arplant.59.032607.092911
Nakano, Y.; Asada, K. Hydrogen peroxide is scavenged by ascorbate-specific peroxidase in spinach chloroplasts. Plant Cell Physiology, v.22, p.867880, 1981. https://doi.org/10.1093/oxfordjournals.pcp.a076232

Nunes, R. L. C.; Dias, N. da S.; Moura, K. K. C. de F.; Souza Neto, O. N. de; Costa, J. M. da. Efeitos da salinidade da solução nutritiva na produção de pimentão cultivado em substrato de fibra de coco. Revista Caatinga, v.26, p.48-53, 2013.

Razavizadeh, R.; Ehsanpour, A. Effects of salt stress on proline content, expression of delta-1-pyrroline-5-carboxylate synthetase, and activities of catalase and ascorbate peroxidase in transgenic tobacco plants. Biological Letters, v.46, p.63-75. 2009. https://doi. org/10.2478/v10120-009-0002-4

Santos, A. N.; Silva, E. F. da F. e; Silva, G. F. da; Barnabé, J. M. C.; Rolim, M. M.; Dantas, D. da C. Yield of cherry tomatoes as a function of water salinity and irrigation frequency. Revista Brasileira de Engenharia Agrícola e Ambiental, v.20, p.107-112, 2016. https:// doi.org/10.1590/1807-1929/agriambi.v20n2p107-112

Soares, T. M.; Silva, E. F. da F. e; Duarte, S. N.; Mélo, R. F.; Jorge, C. de A.; Silva, E. M. B. Produção de alface utilizando águas salinas em sistema hidropônico. Irriga, v.12, p. 235-248, 2007.

Villas Bôas, R. L.; Zanini, J. R.; Duenhas, L. H. Uso e manejo de fertilizantes em fertirrigação. In: Zanini, J. R.; Villas Bôas, R. L.; Feitosa Filho, J. C. (ed.) Uso e manejo da fertirrigação e hidroponia. Jaboticabal: FUNEP, 2002. 65p.

Zhani, K.; Mariem, B. F.; Fardaous, M.; Cherif, H. Impact of salt stress $(\mathrm{NaCl})$ on growth, chlorophyll content and fluorescence of Tunisian cultivars of chili pepper (Capsicum frutescens L.). Journal of Stress Physiology \& Biochemistry, v.8, p.236-252, 2012. 